\title{
Analisa Sifat Mekanik Pengaruh Variasi Perendaman Dan Penekanan Pada Komposit Berbahan Serat Budung
}

\author{
Sutrisno $^{1 *)}$ and $\mathrm{Azmal}^{2)}$ \\ 1,2) Jurusan Teknik Mesin, Politeknik Negeri Pontianak, Kalimantan Barat, Indonesia. \\ Corresponding Email: *idris_tris@yahoo.com
}

\begin{abstract}
This study aims to determine the effect of mechanical properties of impact, bending and tensile of bundung (Actinoscirpus Grossus) fiber composites added $5 \% \mathrm{NaOH}$ with variation of immersion time 0.5 hours, 1 hour and 1.5 hours. Then the blending and casting process is carried out to form a composite material with $20 \%$ fiber and $80 \%$ resin binder with a catalyst content of $1 \%$ and pressurized with press variations of $5 \mathrm{~kg}, 10 \mathrm{~kg}$ and $15 \mathrm{~kg}$. To obtain the result data used several standard tests, namely impact testing (ASTM D 256 - 03), bending (ASTM D 790) and tensile (ASTM D 638 - 03). Impact, bending and tensile strength test results showed that immersion of 0.5 hours with $15 \mathrm{Kg}$ concentration produced the highest value, namely Impact strength $94.89 \mathrm{~J} / \mathrm{mm} 2$, bending strength $17.77 \mathrm{~N} / \mathrm{mm} 2$ and tensile strength $27 \mathrm{~N} / \mathrm{mm} 2$. The test results of the bundung fiber composite in the form of fractures gave the results of the bundung fiber composite test, namely the binder and the fiber breaking evenly at the same point and the fibers were not drawn from the metric.
\end{abstract}

Key words : composites, resins, bundle fibers, mechanical properties.

\section{Pendahuluan}

Tekanan yang meningkat dari aktivis lingkungan, pelestarian sumber daya alam, dan dihadiri keketatan undang-undang yang disahkan oleh negara-negara berkembang yang mengarah ke penemuan dan pengembangan bahan alami dengan fokus pada bahan baku terbarukan yang mengarah ke penemuan dan pengembangan bahan alami dengan fokus pada bahan baku terbarukan. Tidak ada pengaruh yang merugikan terhadap lingkungan dan sifat spesifiknya merupakan penyebab utama yang menarik minat peneliti terhadap komposit serat alam. Produksi berbiaya rendah, konsumsi energi yang lebih sedikit dan ketersediaan yang luas, biodegradabilitas, kepadatan rendah dan kekuatan spesifik yang tinggi adalah alasan utama di balik penggunaan serat selulosa sebagai penyusun komposit serat alami [1].

Dari penelitian-penelitian yang telah dilakukan sebelumnya diketahui bahwa dalam dekade terakhir, polimer telah menjadi bahan yang menarik untuk berbagai aplikasi karena beberapa sifatnya yang terbarukan, termasuk bobot yang ringan, kemudahan pemrosesan dan efektivitas biaya. Oleh karena itu, upaya telah dilakukan secara signifikan untuk memanfaatkan polimer dalam aplikasi industri yang berbeda, menggunakan berbagai jenis penguat termasuk serat yang dimasukkan ke dalam polimer untuk meningkatkan sifat fisik dan mekaniknya. Dengan demikian, komposit matriks polimer yang diperkuat serat sangat menarik karena bobotnya yang ringan, biodegradabilitas, kekuatan tinggi, kekakuan tinggi, resistivitas korosi yang baik, dan koefisien gesekan yang rendah dalam banyak aplikasi yang penting dalam properti mekanis dan tribologis, dari aplikasi rumah tangga hingga ruang angkasa dan, saat ini, bahan ini digunakan di hampir semua bidang kehidupan sehari-hari [2].

Bahan komposit adalah bahan yang terbuat dari dua atau lebih bahan penyusun dengan sifat fisik atau kimia yang berbeda secara signifikan, yang bila digabungkan, menghasilkan bahan dengan karakteristik yang berbeda dari masing-masing komponen. Komposit, dalam banyak kasus, dibuat dengan memperkuat serat dengan resin matriks. Bahan penguatnya bisa berupa serat panjang atau bersambung, partikulat atau partikel halus, dan bahan matriks yang biasa digunakan adalah logam, plastik atau keramik [3].

Penelitian ini dilakukan untuk merancang material komposit baru sebagai pengganti bahan baja dan bukan baja atau serat sintetis lainnya untuk sebagai bahan dasar sudu turbin, komponen otomotif atau elemen mesin lainnya. Dengan bahan penguat komposit adalah serat bundung yang merupakan salah satu jenis rumput yang belum termanfaatkan secara maksimal.

Serat bundung yang digunakan dalam perancangan merupakan salah satu alternatif bahan terbarukan dalam membuat material komposit baru menggantikan peranan logam sebagai bahan dasar pembuatan sudu turbin, komponen otomotif atau elemen mesin lainnya. Material komposit berpenguat serat bundung ini juga diharapkan mempunyai kekuatan mekanik dan sifat yang sesuai dengan rancangan yang diinginkan. Harapan dari terealisasinya penelitian ini adalah dipilihnya serat bundung sebagai penguat komposit karena serat bundung merupakan jenis tanaman rumput yang belum dimanfaat secara maksimal untuk pengganti material lainnya.

\section{Metodologi}

Metode yang dilakukan pada penelitian ini adalah metode eksperimen, dimana bahan bakunya 
menggunakan serat bundung sebagai penguat dan matriks mengunakan resin unsaturated polyester 157 BQTN (UPRs) dengan campuran katalis jenis metyl etyl keton perosida (MEKPO). Pembuatan komposit dengan bahan dasar rumput bundung sebagai serat dan resin sebagai pengikatnya. Serat bundung dan resin dibentuk menjadi material berbentuk produk komposit sesuai standar impact ASTM D 256 - 03, bending ASTM D 790 - 02 dan tarik ASTM D 638 -03. Pada penelitian ini dibuat dengan variasi waktu perendaman, komposisi campuran serat bundung dan resin serta variasi tekanan pada proses casting .

Dalam penelitian ini rumput bundung yang digunakan adalah rumput bundung seperti batang rumput, tetapi mempunyai ruas-ruas yang lebih panjang dan berbentuk segitiga. Memiliki tiga baris daun, berwarna coklat pada tumbuhan yang sudah tua dan berwarna agak keemasan pada tumbuhan yang masih muda memiliki rimpang atau stolon. Rumput jenis ini memiliki tiga sayap dengan lebar sekitar 2-3 cm dan panjang rata-rata $150 \mathrm{~cm}$. Rumput bundung merupakan gulma tahunan yang berumur lebih dari dua tahun. Umumnya hidup di lahan basah yang berair seperti pada rawa-rawa maupun tempat basah lainnya [4]. Rumput bundung dipress dengan alat pengepress dan direndam dengan air tawar selama 24 jam, Gambar. 1, agar mudah untuk memisahkan seratnya.

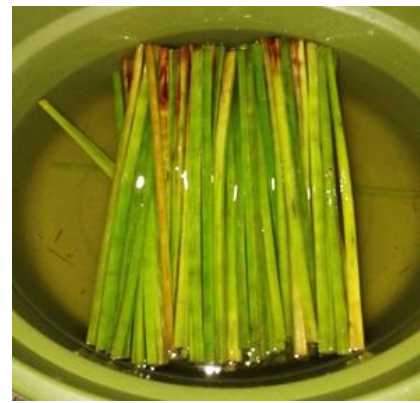

Gambar 1. Rumput bundung dipotong, dipress dan direndam.

Serat bundung diurai menjadi serat dipotong dengan ukuran $170 \mathrm{~mm}$, kemudian serat bundung yang masih basah dijemur, Gambar. 2, setelah kering kemudian direndam dengan $\mathrm{NaOH} 5 \%$ dengan variasi waktu selama 0,5 jam, 1 jam, dan 1,5 jam selanjutnya pengovenan dengan suhu $50 \quad{ }^{0} \mathrm{C}$ untuk mempercepat proses pengeringan.

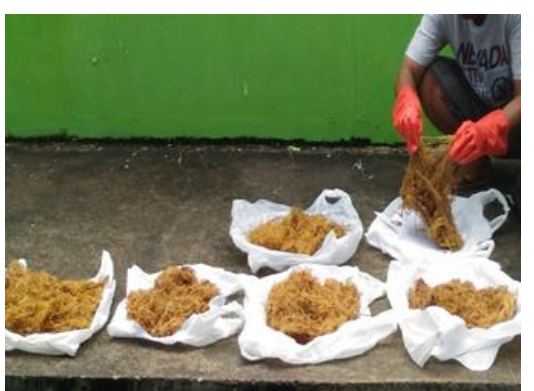

Gambar 2. Pengeringan serat bundung setelah proses perendaman.

Untuk pembuatan komposit dilakukan dengan metode hand lay-up dan secara layer by layer dan menggunakan matrik resin unsaturated polyester 157 BQTN (UPRs) dengan campuran katalis jenis metyl etyl keton perosida (MEKPO). Sedangkan perbandingan campuran antara resin dan katalis adalah $100 \mathrm{cc}$ resin : $1 \mathrm{cc}$ katalis dan kemudian dilakukan proses blending dan casting untuk pembentukan komposit dengan 20\% serat $80 \%$ pengikat, Gambar 3 dan variasi tekanan $5 \mathrm{~kg}, 10 \mathrm{~kg}, 15$ $\mathrm{kg}$, Gambar 4.

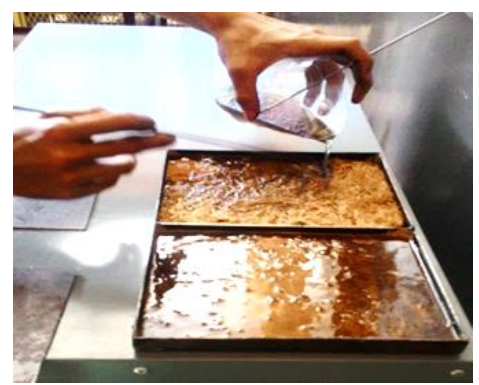

Gambar 3. Pencetakan serat bundung, resin dan katalis.

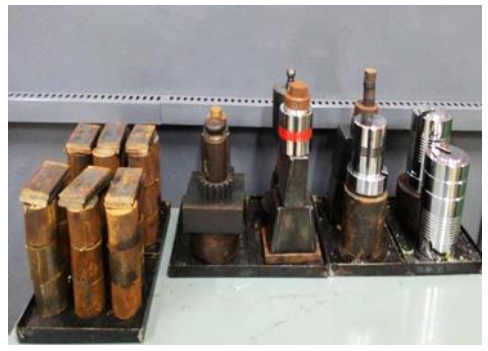

Gambar 4. Pengepresan cetakan serat bundung resin dan katalis.

Bentuk produk komposit sesuai standar impact ASTM D 256-03, bending ASTM D 790 - 02 dan tarik ASTM $D$ 638-03 yang siap untuk dilakukan pengujian, Gambar. 5.

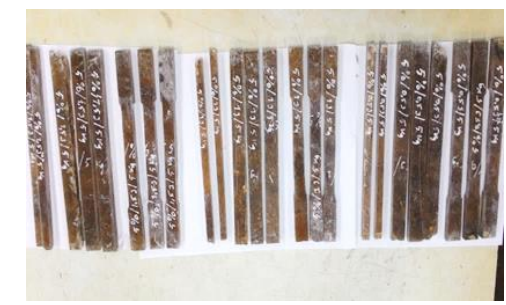

Gambar 5. Sampel komposit untuk pengujian tarik, bengkok dan impact

Pengujian yang akan dilakukan terhadap sampel uji, antara lain uji impact, uji bending dan uji tarik dengan tempat pengujian sampel komposit dilakukan di Laboratorium Pengujian Bahan Jurusan Teknik Mesin Politeknik Negeri Pontianak.

Adapun tahap-tahap penelitian yang dilakukan adalah sebagai berikut:

1. Menyediakan rumput bundung yang memiliki tiga baris daun, berwarna coklat pada tumbuhan yang sudah tua dan berwarna agak keemasan agar serat yang dihasilkan juga akan lebih baik.

2. Setelah rumput bundung direndam selama 24 jam dengan air tawar kemudian dilakukan pengepressan agar batangnya menjadi lunak sehingga lebih mudah untuk memisahkan serat 
dari batangnya.

3. Serat bundung dipotong dengan panjang 170 mm dan dijemur.

4. Dalam eksperimen penelitian ini serat bundung direndam dengan $5 \% \mathrm{NaOH}$ dan variasi waktu perendaman selama 0,5 jam, 1 jam dan 1,5 jam kemudian dikeringkan dengan pengovenan pada suhu $50{ }^{\circ} \mathrm{C}$.

5. Pembuatan komposit (specimen) casting sesuai standar impact ASTM D 256 - 03, bending ASTM D 790 - 02 dan tarik ASTM D 638-03 dengan variasi pengepressan dengan pemberat 5 $\mathrm{kg}, 10 \mathrm{~kg}$ dan $15 \mathrm{~kg}$ serta perbandingan komposit $20 \%$ serat dan $80 \%$ pengikat, dan perbandingan pengikat yaitu resin $100 \mathrm{cc}$ dan katalis $1 \mathrm{cc}$.

6. Kemudian produk komposit dilakukan pengujian impact dengan standar ASTM D 25603, pengujian bending dengan standar ASTM D 790 - 02 dan pengujian tarik dengan standar ASTM D 638 - 03 di Laboratorium Pengujian Bahan Jurusan Teknik Mesin Polnep.

7. Pengambilan data dan pembahasan dari hasil pengujian.

8. Kesimpulan dan laporan hasil penelitian.

Pada penelitian ini untuk mengetahui ketahanan produk komposit terhadap keadaan patah, maka digunakan metode pengujian impact charphy. Dimana batang uji charphy ditunjukkan gambar 6 , mempunyai luas penampang lintang bujur sangkar $(10 \times 10) \mathrm{mm}^{2}$ dengan takikan berbentuk $\mathrm{V}-45^{\circ}$ dengan kedalaman takik $2 \mathrm{~mm}$.
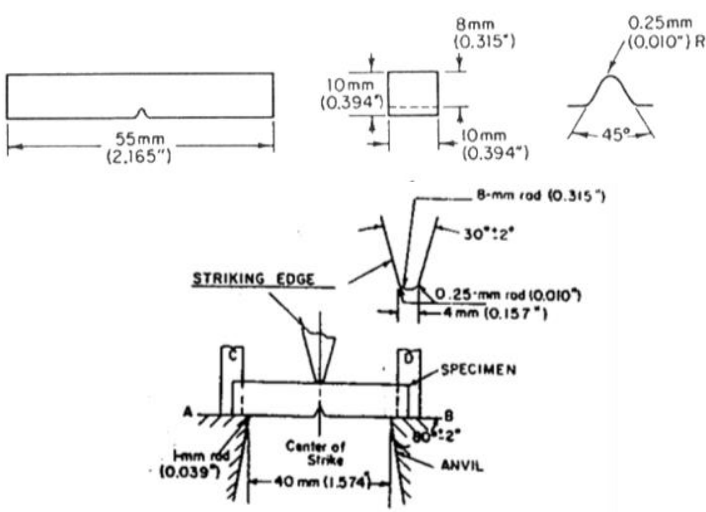

Gambar 6. Dimensi spesimen pengujian impact ASTM D 256-03

Pada metode pengujian impact charphy sebagaimana ditunjukkan pada Gambar. 7, produk komposit diletakkan mendatar dan kedua ujung produk komposit ditumpu pada suatu landasan. Letak takikan (notch) tepat ditengah dengan arah pemukulan dari belakang takikan. Energi yang dipakai untuk mematahkan produk komposit :

$\Delta \mathrm{E}=\left(\mathrm{m} \times \mathrm{g} \times \mathrm{H}_{1}\right)-\left(\mathrm{m} \times \mathrm{g} \times \mathrm{H}_{2}\right)$

$\Delta \mathrm{E}=\mathrm{m} \times \mathrm{g}\left(\mathrm{H}_{1}-\mathrm{H}_{2}\right)$

Dimana :

$\Delta \mathrm{E}=$ energi yang diserap (Joule)

$\mathrm{m}=$ berat podulum $(\mathrm{kg})$.

$\mathrm{g}=$ gravitasi bumi $\left(\mathrm{m} / \mathrm{s}^{2}\right)$

$\mathrm{H}_{1}=$ posisi awal pemukulan $(\mathrm{mm})$.
$\mathrm{H}_{2}=$ posisi akhir pemukulan setelah pemukulan (mm).

Sedang harga kekuatan impak / impact strength $\left(\mathrm{I}_{\mathrm{s}}\right)$ adalah

$\mathrm{I}_{\mathrm{s}} \quad=\Delta \mathrm{E} / \mathrm{A}\left(\mathrm{J} / \mathrm{mm}^{2}\right)$

Dimana :

$\mathrm{I}_{\mathrm{s}} \quad=$ Kekuatan $\operatorname{Impak}\left(\mathrm{J} / \mathrm{mm}^{2}\right)$

$\Delta \mathrm{E} \quad=$ Energi yang diserap $(\mathrm{J})$

A = luas penampang efektif produk komposit $\left(\mathrm{mm}^{2}\right)$

Pengujian bending produk serat komposit mengikuti standar ASTM D790-02 dengan metode three point bending, metode pengujian lihat gambar 7 ini digunakan untuk menentukan kekuatan bending terhadap momen lengkung.
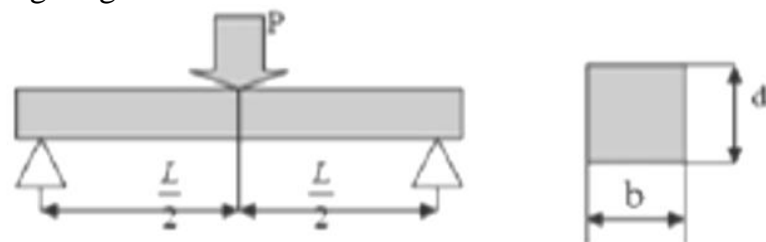

Gambar 7. Penampang uji bending ASTM D 790 - 02.

Momen yang terjadi pada komposit dapat dihitung dengan persamaan :

$$
M=\frac{P}{2} \times \frac{L}{2}
$$

Menentukan kekuatan bending menggunakan persamaan (Standart ASTM D 790 - 02) :

$$
\sigma b=\frac{3 \cdot P \cdot L}{2 \cdot b \cdot d^{2}}
$$

Sedangkan untuk menentukan modulus elastisitas bending menggunakan rumus sebagai berikut (Standar ASTM D790-02) :

$$
\mathrm{E} b=\frac{L^{3} \cdot m}{4 b \cdot d^{3}}
$$

Dimana:

$$
\begin{array}{ll}
\mathrm{M} & =\text { Momen }(\mathrm{Nmm}) \\
\mathrm{L} & =\text { Panjang span }(\mathrm{mm}) \\
\mathrm{P} & =\text { Gaya }(\mathrm{N}) \\
\mathrm{Eb} & =\text { Modulus Elastisitas }(\mathrm{MPa}) \\
\mathrm{\sigma b} & =\text { Kekuatan bending } \\
\mathrm{d} & =\text { Tebal }(\mathrm{mm}) \\
\mathrm{b} & =\text { Lebar }(\mathrm{mm}) \\
\mathrm{m} & =\text { Hubungan tangensial dari kurva defleksi } \\
& (\mathrm{N} / \mathrm{mm})
\end{array}
$$

Pengujian tarik dilakukan untuk mengetahui besarnya kekuatan tarik dari bahan komposit. Pengujian dilakukan dengan mesin uji "Universal Testing Machine". Spesimen pengujian tarik dibentuk menurut standar ASTM D 638-03 yang ditunjukkan pada Gambar. 9 sebagai berikut:

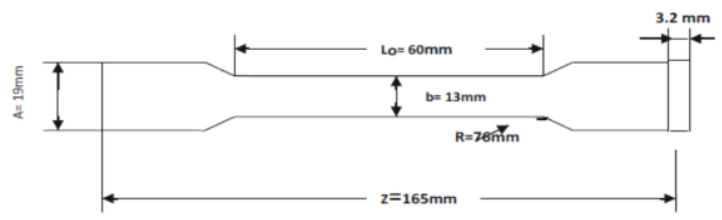

Gambar 9. Dimensi benda pengujian tarik ASTM D 638-03 
Besarnya nilai modulus elastisitas komposit yang juga merupakan perbandingan antara tegangan dan regangan pada daerah proporsional dapat dihitung dengan persamaan:

$\mathrm{E}=\sigma_{R} / \varepsilon$

Dimana:

$\mathrm{E}=$ Modulus elastisitas tarik $\left(\mathrm{N} / \mathrm{mm}^{2}\right)$

$\sigma_{t r}=$ Kekuatan tarik $\left(\mathrm{N} / \mathrm{mm}^{2}\right)$

$\varepsilon=$ Regangan $(\mathrm{mm} / \mathrm{mm})$

Tegangan nominal maksimum yang ditahan oleh batang uji komposit sebelum patah disebut tegangan tarik $\left(\sigma_{t r}\right)$, yaitu merupakan perbandingan antara beban maksimum $\left(\mathrm{F}_{\mathrm{m}}\right)$ yang dicapai selama percobaan tarik dan penampang mula-mula $\left(\mathrm{A}_{\mathrm{o}}\right)$.

$\sigma_{\mathrm{tr}}=\mathrm{F}_{\mathrm{m}} / \mathrm{A}_{\mathrm{o}}$

Dimana:

$\sigma_{t r}=$ Kekuatan tarik $\left(\mathrm{N} / \mathrm{mm}^{2}\right)$

$\mathrm{F}_{\text {maks }}=$ Beban maksimum $(\mathrm{N})$

$\mathrm{A}_{0} \quad=$ Penampang mula-mula $\left(\mathrm{mm}^{2}\right)$

Besarnya regangan adalah jumlah pertambahan panjang karena pembebanan dibandingkan dengan panjang daerah ukur (gage length). Nilai regangan ini adalah regangan proporsional yang didapat dari garis. Proporsional pada grafik tegangan-regangan hasil uji tarik komposit.

$\varepsilon=\Delta \mathrm{L} / \mathrm{L}$

Dimana:

$\Delta \mathrm{L}=$ pertambahan panjang $(\mathrm{mm})$

$\mathrm{L} \quad$ = panjang daerah ukur $(\mathrm{mm})$

\section{Hasil dan Pembahasan}

Pengujian Impact menggunakan delapan jenis bahan komposit yang diolah dari proses perendaman dan pengeringan dengan $5 \% \mathrm{NaOH}$ dan variasi waktu perendaman selama 0,5 jam, 1 jam dan 1,5 jam, kemudian pembuatan komposit dengan $20 \%$ serat dan $80 \%$ pengikat serta penekanan atau pengepressan dengan beban $5 \mathrm{Kg}$, $10 \mathrm{~kg}$ dan $15 \mathrm{Kg}$. Sedangkan Pembuatan dan pengujian komposit (specimen) casting sesuai standar impact ASTM D $256-03$.

Hasil pengujian Impact dapat dilihat pada Tabel.1 sebagai berikut :
Tabel 1. Hasil Pengujian Impact Komposit Serat Bundung.

\begin{tabular}{|c|c|c|c|c|c|c|}
\hline NO. & Nama Benda Uji & Lebar (b) (mm) & Tebal (d) (nm) & $\begin{array}{c}\text { Berat Pendulum } \\
\quad(\mathrm{Kg})\end{array}$ & $\begin{array}{l}\text { Energy } \\
\text { (Joule) }\end{array}$ & $\begin{array}{c}\text { Kekuatan Impact } \\
(\mathrm{J} / \mathrm{mm} 2)\end{array}$ \\
\hline \multirow[t]{6}{*}{ I. } & \multicolumn{6}{|c|}{ A.Tanpa Variasi Perendaman dan Dipress $5 \mathrm{Kg}$} \\
\hline & SBla & 10,07 & 10,33 & 30,40 & 8726,36 & 83,98 \\
\hline & \multicolumn{6}{|c|}{ B. Tanpa Variasi Perendaman dan Dipress $10 \mathrm{Kg}$} \\
\hline & SBlb & 10,83 & 10,50 & 30,40 & 9654,18 & 84,88 \\
\hline & \multicolumn{6}{|c|}{ C. Tanpa Variasi Perendaman dan Dipress $15 \mathrm{Kg}$} \\
\hline & SBlc & 9,90 & 10,20 & 30,40 & 8646,43 & 85,64 \\
\hline \multirow[t]{6}{*}{ II. } & \multicolumn{6}{|c|}{ A. $5 \% \mathrm{NaOH}$ Variasi Perendaman $0,5 \mathrm{Jam}$ dan Dipress $5 \mathrm{Kg}$} \\
\hline & SB2a & 9,67 & 10,43 & 30,40 & 8750,33 & 86,93 \\
\hline & \multicolumn{6}{|c|}{ B. $5 \%$ NaOH Variasi Perendaman $1 \mathrm{Jam}$ dan Dipress $5 \mathrm{Kg}$} \\
\hline & SB2b & 10,00 & 9,50 & 30,40 & 8424,67 & 88,78 \\
\hline & \multicolumn{6}{|c|}{ C. $5 \% \mathrm{NaOH}$ Variasi Perendaman 1,5 Jam dan Dipress $5 \mathrm{Kg}$} \\
\hline & $\mathrm{SB} 2 \mathrm{c}$ & 9,80 & 11,07 & 30,40 & 9553,33 & 88,16 \\
\hline \multirow[t]{6}{*}{ III. } & \multicolumn{6}{|c|}{ A. $5 \%$ NaOH Variasi Perendaman 0,5 Jam dan Dipress $10 \mathrm{Kg}$} \\
\hline & SB3a & 9,80 & 11,07 & 30,40 & 9553,33 & 91,00 \\
\hline & \multicolumn{6}{|c|}{ B. $5 \%$ NaOH Variasi Perendaman 1 Jam dan Dipress $10 \mathrm{Kg}$} \\
\hline & SB3b & 10,93 & 9,70 & 30,40 & 9728,05 & 92,07 \\
\hline & \multicolumn{6}{|c|}{ C. $5 \%$ NaOH Variasi Perendaman 1,5 Jam dan Dipress $10 \mathrm{Kg}$} \\
\hline & $\mathrm{SB3c}$ & 10,40 & 10,27 & 30,40 & 9794,93 & 91,76 \\
\hline \multirow[t]{6}{*}{ IV. } & \multicolumn{6}{|c|}{ A. 5\% NaOH Variasi Perendaman 0,5 Jam dan Dipress $15 \mathrm{Kg}$} \\
\hline & SB4a & 9,33 & 10,33 & 30,40 & 9015,00 & 93,64 \\
\hline & \multicolumn{6}{|c|}{ B. $5 \% \mathrm{NaOH}$ Variasi Perendaman 1 Jam dan Dipress $15 \mathrm{Kg}$} \\
\hline & SB4b & 10,47 & 9,67 & 30,40 & 9487,36 & 94,89 \\
\hline & \multicolumn{6}{|c|}{ C. $5 \% \mathrm{NaOH}$ Variasi Perendaman 1,5 Jam dan Dipress $15 \mathrm{Kg}$} \\
\hline & SBAc & 9,70 & 9,93 & 30,40 & 9056,22 & 94,30 \\
\hline
\end{tabular}

Sedangkan untuk grafik hubungan antara Kekuatan Impact dengan Variasi Perendaman dan Penekanan dapat dilahat pada Gambar. 9 sebagai berikut :

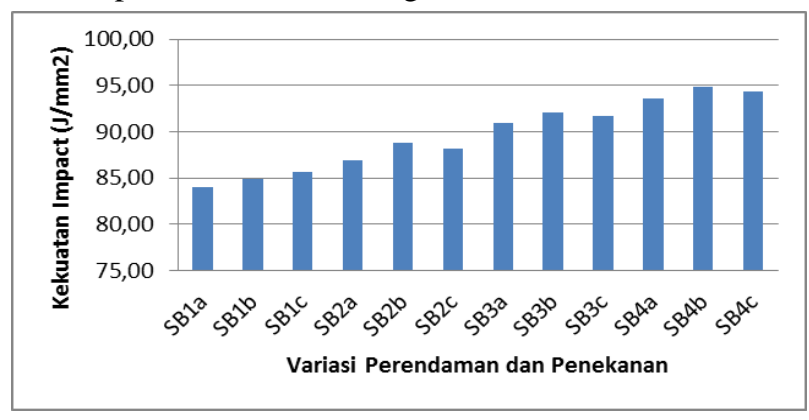

Gambar 9. Garafik Hubungan Kekuatan Impact dengan Variasi Perendaman dan Penekanan.

Pengujian bending proses pembuatan terhadap bahan uji sama dengan pengujian impact, sedangkan bentuk sampel benda uji sesuai dengan sesuai standar bending ASTM D 790 - 02.

Untuk grafik hubungan antara kekuatan bending dengan variasi waktu perendaman dan penekanan dapat dilihat pada Gambar.10 sebagai berikut:

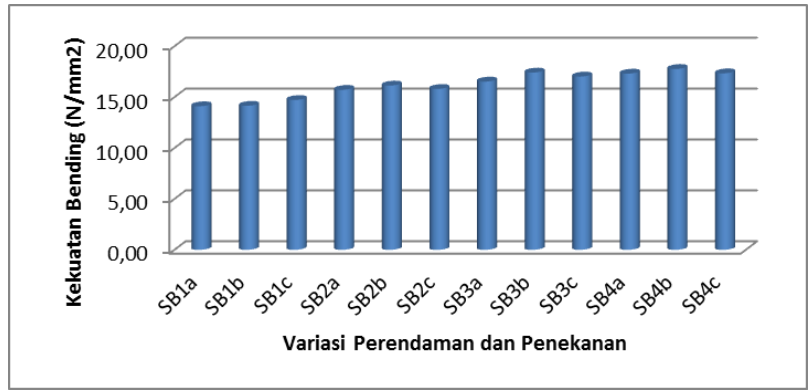

Gambar 10. Grafik hubungan kekuatan bengkok dengan variasi waktu perendaman dan penekanan.

Sedangkan hasil pengujian bending dapat dilihat pada Tabel. 2 sebagai berikut : 
Tabel 2. Hasil Pengujian Bending Komposit Serat Bundung.

\begin{tabular}{|c|c|c|c|c|c|c|}
\hline NO. & Nama Benda Uji & Lebar (b) (mm) & Tebal (d) (mm) & $\begin{array}{l}\text { Jarak Tumpu } \\
(\mathrm{L})(\mathrm{mm})\end{array}$ & $\begin{array}{c}\text { Gaya Bengkok) } \\
(\mathrm{F})(\mathrm{N})\end{array}$ & $\begin{array}{c}\text { Tegangan Bengkok } \\
(\sigma b)(M P a)\end{array}$ \\
\hline \multirow[t]{6}{*}{ I. } & A. Tanpa Variasi Pe & daman dan Dipres & $5 \mathrm{Kg}$ & & & \\
\hline & SBla & 19,73 & 10,27 & 120,00 & 163,33 & 14,11 \\
\hline & B. Tanpa Variasi Per & laman dan Dipres & $10 \mathrm{Kg}$ & & & \\
\hline & SBlb & 20,03 & 9,67 & 120,00 & 50,00 & 14,15 \\
\hline & C. Tanpa Variasi Per & laman dan Dipres & $15 \mathrm{Kg}$ & & & \\
\hline & SBlc & 20,10 & 10,07 & 120,00 & 166,67 & 14,72 \\
\hline \multirow[t]{6}{*}{ II. } & A. $5 \% \mathrm{NaOH}$ Varias & rendaman $0.5 \mathrm{Jan}$ & lan Dipress $5 \mathrm{Kg}$ & & & \\
\hline & SB2a & 20,40 & 10,10 & 120,00 & 181,67 & 15,72 \\
\hline & B. $5 \%$ NaOH Variasi & rendaman $1 \mathrm{Jamd}$ & D Dipress $5 \mathrm{Kg}$ & & & \\
\hline & SB2b & 19,83 & 9,97 & 120,00 & 176,67 & 16,14 \\
\hline & C. 5\% NaOH Variasi & rendaman $1,5 \mathrm{Jam}$ & an Dipress $5 \mathrm{Kg}$ & & & \\
\hline & $\mathrm{SB} 2 \mathrm{c}$ & 19,07 & 10,67 & 120,00 & 190,00 & 15,81 \\
\hline \multirow[t]{6}{*}{ IIII. } & A. $5 \%$ NaOH Varias & rendaman $0,5 \mathrm{Jam}$ & $\operatorname{lan}$ Dipress $10 \mathrm{Kg}$ & & & \\
\hline & SB3a & 21,27 & 9,20 & 120,00 & 165,00 & 16,53 \\
\hline & B. $5 \%$ NaOH Variasi & rendaman $1 \mathrm{Jamd}$ & n Dipress $10 \mathrm{Kg}$ & & & \\
\hline & SB3b & 21,13 & 9,63 & 120,00 & 190,00 & 17,42 \\
\hline & C. $5 \%$ NaOH Variasi & rendaman $1,5 \mathrm{Jam}$ & an Dipress $10 \mathrm{Kg}$ & & & \\
\hline & SB3c & 20,57 & 10,63 & 120,00 & 220,00 & 17,03 \\
\hline \multirow[t]{6}{*}{ IV. } & A. $5 \% \mathrm{NaOH}$ Varias & rendaman $0,5 \mathrm{Jam}$ & lan Dipress $15 \mathrm{Kg}$ & & & \\
\hline & SB4a & 19,77 & 9,73 & 120,00 & 180,00 & 17,31 \\
\hline & B. $5 \% \mathrm{NaOH}$ Variasi & rendaman 1 Jamd & $\mathrm{n}$ Dipress $15 \mathrm{Kg}$ & & & \\
\hline & $\begin{array}{c}\mathrm{SB} 4 \mathrm{~b} \\
\end{array}$ & 18,57 & 9,53 & 120,00 & 166,67 & 17,77 \\
\hline & C. $5 \% \mathrm{NaOH}$ Variasi & rendaman $1,5 \mathrm{Jam}$ & an Dipress $15 \mathrm{Kg}$ & & & \\
\hline & $\mathrm{SB} 4 \mathrm{c}$ & 21,90 & 9,57 & 120,00 & 193,33 & 17,34 \\
\hline
\end{tabular}

Benda uji yang dibuat pada pengujian tarik mempunyai proses dan perlakuan yang sama pada pengujian Impact, sedangkan pembuatan dan pembentukan sampel menyesuaikan standar tarik ASTM D 638 - 03 .

Untuk hasil pengujian kekuatan tarik dapat dilihat pada Tabel. 3 sebagai berikut :

Tabel 3. Hasil Pengujian Tarik Komposit Serat Bundung.

\begin{tabular}{|c|c|c|c|c|}
\hline No. & Nama Benda Uji & $\begin{array}{c}\text { Luasan Benda Uji } \\
(\mathrm{mm} 2)\end{array}$ & $\begin{array}{c}\text { Gaya Tarik } \\
\text { Maksimum }(\mathrm{N})\end{array}$ & $\begin{array}{l}\text { Kekuatan Tarik } \\
\left(\sigma_{\text {mak }}\right)(\mathrm{N} / \mathrm{mm} 2)\end{array}$ \\
\hline \multirow[t]{6}{*}{ I. } & \multicolumn{4}{|c|}{ A. Tanpa Variasi Perendaman dan Dipress $5 \mathrm{Kg}$} \\
\hline & SBla & 141,00 & 480,00 & 3,40 \\
\hline & \multicolumn{4}{|c|}{ B. Tanpa Variasi Perendaman dan Dipress $10 \mathrm{Kg}$} \\
\hline & SBlb & 143,33 & 513,33 & 3,58 \\
\hline & \multicolumn{4}{|c|}{ C. Tanpa Variasi Perendaman dan Dipress $15 \mathrm{Kg}$} \\
\hline & SBlc & 144,67 & 533,33 & 3,69 \\
\hline \multirow[t]{6}{*}{ II. } & \multicolumn{4}{|c|}{ A. 5\% $\mathrm{NaOH}$ Variasi Perendaman 0,5 Jam dan Dipress $5 \mathrm{Kg}$} \\
\hline & SB2a & 149,67 & 756,67 & 5,05 \\
\hline & \multicolumn{4}{|c|}{ B. $5 \% \mathrm{NaOH}$ Variasi Perendaman $1 \mathrm{Jam}$ dan Dipress $5 \mathrm{Kg}$} \\
\hline & SB2b & 156,67 & 860,00 & 5,48 \\
\hline & \multicolumn{4}{|c|}{ C. 5\% $\mathrm{NaOH}$ Variasi Perendaman 1,5 Jam dan Dipress $5 \mathrm{Kg}$} \\
\hline & SB2c & 153,33 & 800,00 & 5,21 \\
\hline \multirow[t]{6}{*}{ III. } & \multicolumn{4}{|c|}{ A. $5 \% \mathrm{NaOH}$ Variasi Perendaman 0,5 Jam dan Dipress $10 \mathrm{Kg}$} \\
\hline & SB3a & 150,00 & 760,00 & 5,07 \\
\hline & \multicolumn{4}{|c|}{ B. 5\% NaOH Variasi Perendaman $1 \mathrm{Jam}$ dan Dipress $10 \mathrm{Kg}$} \\
\hline & SB3b & 134,33 & 833,33 & 6,31 \\
\hline & \multicolumn{4}{|c|}{$\begin{array}{l}\text { C. } 5 \% \mathrm{NaOH} \text { Variasi Perendaman 1,5 Jam dan Dipress } 10 \mathrm{Kg} \\
\end{array}$} \\
\hline & $\mathrm{SB} 3 \mathrm{c}$ & 150,00 & 780,00 & 5,20 \\
\hline \multirow[t]{6}{*}{ IV. } & \multicolumn{4}{|c|}{ A. $5 \% \mathrm{NaOH}$ Variasi Perendaman 0,5 Jam dan Dipress $15 \mathrm{Kg}$} \\
\hline & SB4a & 146,67 & 893,33 & 6,09 \\
\hline & \multicolumn{4}{|c|}{ B. $5 \% \mathrm{NaOH}$ Variasi Perendaman $1 \mathrm{Jam}$ dan Dipress $15 \mathrm{Kg}$} \\
\hline & SB4b & 146,67 & 1066,67 & 7,27 \\
\hline & \multicolumn{4}{|c|}{ C. $5 \% \mathrm{NaOH}$ Variasi Perendaman 1,5 Jam dan Dipress $15 \mathrm{Kg}$} \\
\hline & SB4b & 148,33 & 1020,00 & 6,87 \\
\hline
\end{tabular}

Sedangkan untuk grafik hubungan antara Kekuatan Tarik dengan Variasi Perendaman dan Penekanan dapat pada Gambar. 11 sebagai berikut:

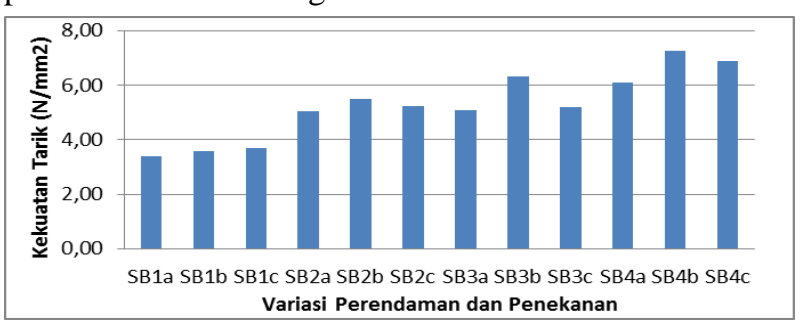

Gambar 11. Garafik hubungan kekuatan tarik dengan variasi waktu perendaman dan penekanan.

Pengujian impact untuk komposit serat bundung dengan perbandingan $20 \%$ serat dan $80 \%$ pengikat tanpa perlakuan variasi waktu perendaman dan variasi penekanan pada $15 \mathrm{Kg}$ yang mempunyai kekuatan impact paling tinggi yaitu $85,64 \mathrm{~J} / \mathrm{mm}^{2}$. Untuk dengan variasi perendaman dan penekanan $5 \mathrm{Kg}$, kekuatan impact yang paling besar pada perendaman 1 jam yaitu $88,78 \mathrm{~J} / \mathrm{mm} 2$. Pada variasi perendaman dan penekanan $10 \mathrm{Kg}$, kekuatan Impact yang paling besar pada perendaman 1 jam yaitu $92,07 \mathrm{~J} / \mathrm{mm}^{2}$. Sedangkan untuk variasi perendaman dan penekanan $15 \mathrm{Kg}$, kekuatan Impact yang paling besar pada perendaman 1 jam yaitu $94,89 \mathrm{~J} / \mathrm{mm}^{2}$. Jadi kekuatan impact pada variasi waktu perendaman 1 jam dengan variasi penekatan $15 \mathrm{Kg}$ yang paling besar nilainya yaitu $94,89 \mathrm{~J} / \mathrm{mm}^{2}$.

Pengujian bending untuk komposit serat bundung dengan perbandingan $20 \%$ serat dan $80 \%$ pengikat tanpa perlakuan variasi perendaman dan dengan variasi penekanan untuk $15 \mathrm{Kg}$ kekuatan bending paling tinggi yaitu $14,72 \mathrm{~N} / \mathrm{mm}^{2}$. Pada variasi perendaman dan penekanan $5 \mathrm{Kg}$, kekuatan bending yang paling besar pada perendaman 1 jam yaitu $16,14 \mathrm{~N} / \mathrm{mm}^{2}$. Pada variasi perendaman dan penekanan $10 \mathrm{Kg}$, kekuatan bending yang paling besar pada perendaman 1 jam yaitu 17,42 $\mathrm{N} / \mathrm{mm}^{2}$. Sedangkan untuk variasi perendaman dan penekanan $15 \mathrm{Kg}$, kekuatan bending yang paling besar pada perendaman 1 jam yaitu $17,77 \mathrm{~N} / \mathrm{mm}^{2}$. Jadi kekuatan bending tanpa variasi atau dengan variasi perendaman serta dengan variasi penekanan kekuatan bending pada perendaman 1 jam dengan penekatan $15 \mathrm{Kg}$ yaitu 17,77 $\mathrm{N} / \mathrm{mm}^{2}$.

Sedangkan untuk kekuatan tarik dengan perbandingan $20 \%$ serat dan $80 \%$ pengikat tanpa perlakuan variasi perendaman dan dengan variasi penekanan bahwa pada penekanan $15 \mathrm{Kg}$ kekuatan tarik paling tinggi yaitu 3,58 $\mathrm{N} / \mathrm{mm}^{2}$. Sedangkan dengan variasi waktu perendaman dan penekanan $5 \mathrm{Kg}$, kekuatan tarik yang paling besar pada perendaman 1 jam yaitu $5,48 \mathrm{~N} / \mathrm{mm}^{2}$. Pada variasi waktu perendaman dan penekanan $10 \mathrm{Kg}$, kekuatan tarik yang paling besar pada perendaman 1 jam yaitu 6,31 $\mathrm{N} / \mathrm{mm}^{2}$. Pada variasi waktu perendaman dan penekanan $15 \mathrm{Kg}$, kekuatan tarik yang paling besar pada perendaman 1 jam yaitu 7,27 N/mm2.

Jadi kekuatan tarik komposit serat bundung dengan variasi waktu perendaman 1 jam dan penekanan $15 \mathrm{Kg}$ mempunyai kekuatan tarik yang paling besar yaitu 7,27 $\mathrm{N} / \mathrm{mm}^{2}$.

Dari data-data diatas menunjukkan bahwa hasil pengujian kekuatan Impact, kekuatan bending dan kekuatan tarik ada peningkatan kekuatan dengan meningkatnya penekanan yang dilakukan pada proses pembuatan komposit (specimen) casting, sehingga serat dan pengikat mengikat dengan membentuk mikrostruktur yang padat. Ini dapat dilihat dari bentuk patahan dari tiga hasil pengujian Impact, bending dan tarik yaitu pengikat dan serat putus merata pada satu titik yang sama serta serat tidak tercabut dari matriknya. Pada proses perendaman serat bundung juga mempengaruhi kekuatan dari serat dimana perendaman dengan $5 \% \mathrm{NaOH}$ tidak boleh lebih atau kurang dari 1 jam, dan juga penyebaran serat dalam proses pembuatan komposit (specimen) casting juga sangat mempengaruhi terhadap kekuatan daari bahan komposit. 


\section{Kesimpulan}

Berdasarkan dari hasil penelitian, dapatlah disimpulkan sebagai berikut:

Kekuatan impact, bending dan tarik yang tertinggi dihasilkan dari komposit serat bundung dengan perendaman $5 \% \mathrm{NaOH}$, variasi waktu dan penekanan yaitu pada perendaman 1 jam dengan penekanan $15 \mathrm{Kg}$.

Bentuk patahan dari hasil pengujian impact, bending dan tarik komposit serat bundung yaitu pengikat dan serat putus merata pada satu titik yang sama serta serat tidak tercabut dari metriknya

Metode dan proses yang dilakukan pada komposit serat bundung ini merupakan salah satu cara untuk digunakan mengetahui kekuatan mekanik dan sifat bahan komposit lainnya sehingga mempermudah perancang dalam pemilihan bahan dalam perancangannya.

\section{UCAPAN TERIMA KASIH}

Ucapan terimakasih disampaikan kepada pimpinan lembaga dan struktural Jurusan Teknik Mesin, pengelola Laboratorium Pengujian Bahan Jurusan Teknik Mesin Politeknik Negeri Pontianak yang telah berkonstribusi dan membantu dalam pendanaan dan proses penelitian yang dilakukan hingga penulisan dalam makalah ini. Dan tak lupa juga ucapan terima kasih kepada rekan sejawat dan mahasiswa Jurusan Teknik Mesin serta pihak-pihak yang tidak dapat sebutkan satu persatu yang telah membantu dalam proses pembuatan artikel ini hingga diterbitkan.

\section{Daftar Pustaka}

[1] Mohit Sood, Gaurav Dwivedi (2017), Effect of fiber treatment on flexural properties of natural fiber reinforced composites, Egyptian Journal of Petroleum xxx (2017).

[2] Emad Omrani, Pradeep L. Menezes b, Pradeep K (2016), Rohatgi State of the art on tribological behavior of polymer matrix composites reinforced with natural fibers in the green materials world, Engineering Science and Technology, an International Journal 19 (2016) 717 736.

[3] Onkar V. Potadara, Ganesh S. Kadama (2018), Preparation and Testing of Composites using Waste Groundnut Shells and Coir Fibres, Procedia Manufacturing 20 (2018) 91-96.

[4] Sitohang, N. 2015. Studi Pemanfaatan Rumput Bundung (Scirpus Grossus Linne) Sebagai Serat Alami Bahan Alat Penangkapan Ikan Dengan Pengujian Kekuatan Putus (Breaking Strength) Dan Kemuluran (Elongation). Fakultas Perikanan Dan Ilmu Kelautan . Universitas Riau. Pekanbaru. 70 hal. (Tidak diterbitkan)

[5] ASTM D 256, Standart Test Methde for determining charpy impact sffength af Plastic. American Sosiety for Testing Materials, Philadelphi4 PA.

[6] ASTM. D 790 - 02, Standard test methods for flexural properties of unreinforced and reinforced plastics and electrical insulating material. Philadelphia, PA : American Society for Testing and Materials.
[7] ASTM International, The Composite Materials Handbook, Polymers Matrix Composite, volume 3. Baltimore, USA.

[8] R. Pragatheeswaran, S. Senthil Kumaran (2015), Mechanical behaviour of groundnut shell powder/calcium carbonate/vinyl ester composite, International Journal of Current Engineering and Scientific Research, 2 (2015) 28-31.

[9] A. Atiqah, M. jawaid, M.R. Ishak, S.M. Sapuan (2017), Moisture Absorption and Thickness Swelling Behaviour of Sugar Palm Fibre Reinforced Thermoplastic Polyurethane, Procedia Engineering 184 ( 2017 ) 581586.

[10] Onkar V. Potadar, Akshay A. Pashilkar, Anson Z. Abraham, Dipak S. Chavan, Meljo Saji, Preparation and testing of composite materials (2016), Unpublished Thesis-SIES GST, Nerul, Navi Mumbai, M.S., India, 2016.

[11] D. Tchepel, F.A.O. Fernandes, O. Anjos, R.J. Alves de Sousa (2016). Mechanical properties of natural cellular materials. In: Reference Modules in Materials Science and Materials Engineering, Elsevier, 2016.

[12] William D. Callister, Jr., David G. Rethwisch (2014), Materials Science and Engineering, Wiley USA, 2014.

[13] Krishan K. Chawla (2013), Composite Materials, Springer New York, 2013. 